\title{
LAHAN PERTANIAN PANGAN BERKELANJUTAN DI KABUPATEN INDRAGIRI HILIR
}

KMS. Novyar Satriawan Fikri ${ }^{1}$, Mulono Apriyanto ${ }^{2}$, Rifni Novitasari ${ }^{3}$

${ }^{1}$ Prodi Ilmu Hukum, Fakultas Hukum, Universitas Islam Indragiri

${ }^{2,3}$ Prodi Teknologi Pangan, Fakultas Pertanian, Universitas Islam Indragiri

Email: mulonoapriyanto71@gmail.com (korespondensi)

\begin{abstract}
Food agricultural land is the part of the cultivation function land. The population growth rate in Indragiri Hilir Regency reaches 4.66 percent per year. The increase in population growth in Indragiri Hilir Regency has an impact on increasing the need or demand for food which is quite high. From these problems, this study was prepared by identifying the Areas of Sustainable Food Agriculture (LP2B). The purpose of this research is to know the juridical basis, the philosophical basis and the sociological basis. It is concluded that there will be serious problems with the decrease in the area of agricultural land.
\end{abstract}

Keywords: Sustainable Food Agricultural Land, Rice Self Sufficiency, Supplies Wetland

\begin{abstract}
Abstrak
Lahan pertanian pangan merupakan bagian dari lahan fungsi budidaya. Laju pertumbuhan penduduk di Kabupaten Indragiri Hilir mencapai 4,66 persen per tahun, Peningkatan pertumbuhan penduduk di Kabupaten Indragiri Hilir berdampak pada peningkatan kebutuhan atau permintaan (deman) pangan yang cukup tinggi. Dari pokokpermasalahan tersebut disusunlah studi ini dengan mengidentifikasi Kawasan Lahan Pertanian Pangan Berkelanjutan (LP2B). Adapun tujuan dari penelitian ini mengetahui landasan yuridis, landasan filosofis dan landasan sosiologis. Disimpulkan bahwa akan terjadi permasalahan serius dengan penurunan luas lahan pertanian.
\end{abstract}

Kata kunci: Lahan Pertanian Pangan Berkelanjutan, Swasembada Beras, Kebutuhan Lahan

Sawah

\section{Pendahuluan}

Lahan pertanian Pangan Berkelanjutan tidak lepas dari permasalahan ketahanan pangan yang mencakup 3 aspek penting, yaitu: ketersediaan (supply) baik lahan ataupun hasil, pendistribusian dan konsumsi. Menurut UndangUndang Nomor 26 tahun 2007 tentang Penataan Ruang mengamanatkan pentingnya mengalokasikan lahan untuk pertanian pangan secara terus menerus. Amanat tersebut telah dikuatkan dengan disahkannya Undang-Undang Nomor 41 Tahun 2009 tentang Perlindungan Lahan Pertanian Pangan Berkelanjutan (PLP2B). Undang-Undang No.41/2009 ini diharapkan dapat menekan tingginya laju konversi lahan sawah dan mempertahankan fungsi ekologinya dan juga Undang-undang ini menyatakan bahwa penyusunan Kawasan
Lahan Pertanian Pangan Berkelanjutan (LP2B) dan Lahan Cadangan Pertanian Pangan Berkelanjutan (LCP2B) wajib dilakukan oleh pemerintah sebagai upaya untuk menjamin keberlanjutan pasokan pangan untuk masyarakat dan sebagai upaya perlindungan terhadap lahan lahan pertanian subur dengan produktivitas tinggi[1].

Kabupaten Indragiri Hilir resmi menjadi Daerah Tingkat II berdasarkan Undang undang No.6 tahun 1965 tanggal 14 Juni 1965 (LN RI No.49). Daerah ini terletak dibagian selatan Propinsi Riau dengan luas wilayah $11.605,97 \mathrm{~km} 2$ dalam posisi : 0o 36" Lintang Utara 1 o 07" Lintang Selatan 104 o 10" Bujur Timur 102 ○ 32" Bujur Timur. Pada tahun 2005 Wilayah Administrasi Pemerintahan daerah ini terdiri dari 20 Kecamatan, 18 Kelurahan dan 174 
desa. Pada tahun 2011, jumlah kelurahan dan desa di Kabupaten Indragiri Hilir mengalami penambahan karena adanya pemekaran desa yaitu menjadi 203 desa dan 33 kelurahan [2], [3].

\section{TINJAUAN PUSTAKA}

\subsection{Kajian Teoritik}

Alih Fungsi Lahan adalah suatu proses perubahan penggunaan lahan dari bentuk penggunaan tertentu menjadi penggunaan lain misalnya ke non pertanian, dan biasanya dalam pengalih fungsiannya mengarah ke hal yang bersifat negatif bagi ekosistem lingkungan alam sawah itu sendiri. Alih fungsi lahan terjadi sebagai akibat pertumbuhan ekonomi dan pertambahan jumlah penduduk yang terus meningkat [3]. Hal tersebut tercermin dari pertumbuhan aktivitas pemanfaatan sumber daya alam yang didorong oleh meningkatnya permintaan kebutuhan terhadap penggunaan lahan serta adanya pergeseran kontribusi sektorsektor pembangunan primer, khususnya dari sektor pertanian dan pengolahan sumber daya ke sektor sekunder (manufaktur) dan sektor tersier (jasa)[3]-[5].

\subsection{Sistem Pertanian Berkelanjutan}

Secara garis besar [6] mengemukakan kriteria sistem pertanian berkelanjutan, yakni: Keberlanjutan ekonomi berarti juga meminimalkan atau bahkan meniadakan biaya eksternal dalam proses produksi pertanian [7], [8]. Keberlanjutan ekologis adalah upaya mengembangkan agroekosistem agar memiliki kemampuan untuk bertahan dalam kurun waktu yang lama melalui pengelolaan terpadu untuk memelihara dan mendorong peningkatan fungsi sumber daya alam yang ada. Pengembangan sistem juga berorientasi pada keragaman hayati (biodiversity)[9]. Syarat mutlak sistem pertanian berkelanjutan adalah keadilan sosial, dan kesesuaian dengan budaya lokal, yakni penghargaan martabat dan hak asasi individu serta kelompok untuk mendapat perlakuan adil [10], [11].

\subsection{Konsep Perlindungan Lahan Pertanian Pangan Berkelanjutan \\ Pertanian berkelanjutan adalah} sumberdaya untuk menghasilkan kebutuhan pokok manusia, yaitu sandang, pangan dan papan, sekaligus mempertahankan dan meningkatkan kualitas lingkungan dan melestarikannya. Defisnisi hal - hal tersebut mencangkup penataan secara ekologi, bisa berlanjut secara ekonomi, adil, manusiawi, dan luwes [12]. Persepi adalah pengalaman seseorang tentang obyek, peristiwa atau hubungan-hubungan yang diperoleh dengan menyimpulkan informasi dan menafsirkan pesan. Persepsi adalah pandangan atau sikap terhadap sesuatu hal yang menumbuhkan motivasi, dorongan, kekuatan dan tekanan yang menyebabkan seseorang melakukan atau tidak melakukan sesuatu [13], [14].

Ancaman terhadap terganggunya ketahanan pangan akibat dari maraknya konversi sangat signifikan.Banyak daerahyang sebelumnya merupakan wilayah swasembada beras saat ini telah menjadi daerah yang mengimpor beras dari daerahdaerah lainnya. Ancaman terhadap ketahanan pangan ini tidak saja menyebabkan berkurangnya produksi beras tapi juga akan menganggu terhadap stabilitas ekonomi, sosial, politik dan perkembangan penduduk secara umum.

\section{METODOLOGI PENELITIAN}

Penelitian mengenai implementasi program perlindungan lahan pertanian pangan berkelanjutan ini dilakukan di Kabupaten Indragiri Hilir Provinsi Riau. Pemilihan lokasi ini dilakukan dengan pruposive, dengan pertimbangan bahwa rawan terjadinya alih fungsi lahan. Pengumpulan data dilakukan pada bulan September 2019.

Analisis data dilakukan secara kualitatif dan kuantitatif. data kualitatif menggunakan analisis deskriptif yang berguna untuk menganalisis data yang menggambarkan, meringkas berbagai kondisi, dan berbagai situasi program PLP2B dan mendeskriptifkan persepsi tingkat kepentingan petani terhadap atribut program PLP2B.

\section{HASIL DAN PEMBAHASAN}

\subsection{Landasan Yuridis}

Pemerintah Kabupaten Indragiri Hilir melakukan penetapan kawasan lahan perlindungan pertanian pangan berkelanjutan sebagai langkah mengantisipasi terus berkurang berkurangnya lahan pertanian, sekaligus juga merealisasikan amanat UU no 41 Tahun 2009 dan Perda no 29 Tahun 2011 tentang Rancana Tata Ruang dan Wilayah Kabupaten Garut. Salah satu upaya Pemerintah Kabupaten Garut dalam mencegah alih fungsi lahan pertanian pangan yaitu dengan Program Perlindungan Lahan Pertanian Pangan Berkelanjutan (PLP2B). Program Perlindungan Lahan Petanian Pangan Berkelanjutan di Kabupaten Indragiri Hilir berdasarkan :

1. Pasal 18 ayat (6) Undang-Undang Dasar Negara Republik Indonesia Tahun 1945; 
2. Undang-Undang Nomor 6 Tahun 1965 tentang Pembentukan Daerah Tingkat II Indragiri Hilir dengan mengubah UndangUndang Nomor 12 Tahun 1956 tentang Pembentukan Daerah Otonom Kabupaten Dalam Lingkungan Daerah Provinsi Sumatera Tengah (Lembaran Negara Republik Indonesia Tahun 1965 Nomor 49, Tambahan Lembaran Negara Republik Indonesia Nomor 2574);

3. Undang-Undang Nomor 26 Tahun 2007 tentang Penataan Ruang (Lembaran Negara Republik Indonesia Tahun 2007 Nomor 26, Tambahan Lembaran Negara Republik Indonesia Nomor 4725);

4. Undang-Undang Nomor 41 Tahun 2009 tentang Perlindungan Lahan Pertanian Pangan Berkelanjutan (Lembaran Negara Republik Indonesi Tahun 2009 Nomor 149, Tambahan Lembaran Negara Republik Indonesia Nomor 5068);

5. Undang-Undang Nomor 12 Tahun 2011 tentang Pembentukan Peraturan Perundangundangan (Lembaran Negara Republik Indonesia Tahun 2011 Nomor 82, Tambahan Lembaran Negara Republik Indonesia Nomor 5234)sebagaimanaa telah diubah dengan Undang-Undang Nomor 15 Tahun 2019 tentang Perubahan Atas Undang - Undang Nomor 12 Tahun 2011 tentang Pembentukan Peraturan Perundang-Undangan (Lembaran Negara Republik Indonesia Nomor 5280);

6. Undang-Undang Nomor 2 Tahun 2012 tentang Pengadaan Tanah Bagi Pembangunan Untuk Kepentingan Umum (Lembaran Negara Republik Indonesia Tahun 2012 Nomor 22, Tambahan Lembaran Negara Republik Indonesia Nomor 5280);

7. Undang-Undang Nomor 18 Tahun 2012 tentang Pangan (Lembaran Negara Republik Indonesia Tahun 2012 Nomor 227, Tambahan Lembaran Negara Republik Indonesia Nomor 5360);

8. Undang-Undang Nomor 23 Tahun 2014 tentang Pemerintahan Daerah (Lembaran Negara Republik Indonesia Tahun 2014 Nomor 244, Tambahan Lembaran Negara Republik Indonesia Nomor 5587) sebagaimana telah diubah dengan UndangUndang Nomor 9 Tahun 2015 (Lembaran Negara Republik Indonesia Tahun 2015 Nomor 58, Tambahan Lembaran Negara Republik Indonesia Nomor5679);

9. Peraturan Pemerintah Nomor 10 Tahun 2010 tentang Tata Cara Perubahan Peruntukan dan Fungsi Kawasan Hutan (Lembaran Negara Republik Indonesi Tahun 2010 Nomor 15,
Tambahan Lembaran Negara Republik Indonesia Nomor 5097);

10. Peraturan Pemerintah Nomor 1 Tahun 2011 tentang Penetapan dan Alih Fungsi Lahan Pertanian Pangan Berkelanjutan (Lembaran Negara Republik Indonesi Tahun 2011 Nomor 2, Tambahan Lembaran Negara Republik Indonesia Nomor 5185);

11. Peraturan Pemerintah Nomor 12 Tahun 2012 tentang Insentif Perlindungan Lahan Pertanian Pangan Berkelanjutan (Lembaran Negara Republik Indonesi Tahun 2012 Nomor 19, Tambahan Lembaran Negara Republik Indonesia Nomor 5179);

12. Peraturan Pemerintah Nomor 25 Tahun 2012 tentang Sistem

13.Informasi Lahan Pertanian Pangan Berkelanjutan (Lembaran Negara Republik Indonesi Tahun 2012 Nomor 46, Tambahan Lembaran Negara Republik Indonesia Nomor 5283)

14. Peraturan Pemerintah Nomor 30 Tahun 2012 tentang Pembiayaan Perlindungan Lahan Pertanian Pangan Berkelanjutan (Lembaran Negara Republik Indonesia Tahun 2012 Nomor 55, Tambahan Lembaran Negara Republik Indonesia Nomor 5288);

15.Peraturan Pemerintah Nomor 104 Tahun 2015 tentang Tata Cara Perubahan Peruntukan Dan Fungsi Kawasan Hutan (Lembaran Negara Republik Indonesi Tahun 2015 Nomor 326, Tambahan Lembaran Negara Republik Indonesia Nomor 5794);

16. Peraturan Pemerintah Nomor 12 Tahun 2017 tentang Pembinaan dan Pengawasan Penyelenggaraan Pemerintahan Daerah (Lembaran Negara Republik Indonesia Tahun 2017 Nomor 73, Tambahan Lembaran Negara Republik Indonesia Nomor 6041);

17.Peraturan Menteri Dalam Negeri Nomor 80 Tahun 2015 tentang Pembentukan Produk Hukum Daerah (Berita Negara Republik Indonesia Tahun 2015 Nomor 2036) sebagaimana telah diubah dengan Peraturan Atas Peraturan Menteri Dalam Negeri 120 Tahun 2018 tentang Perubahan Atas Peraturan Menteri Dalam Negeri Nomor 80 Tahun 2015 Tentang Pembentukan Produk Hukum Daerah (Berita Negara Republik Indonesia Tahun 2018 Nomor 157);

18. Peraturan Daerah Provinsi Riau Nomor 10 Tahun 2018 tentang Rencana Tata Ruang Wilayah Provinsi Riau Tahun 2018-2038;

19.Peraturan Menteri ATR Nomor 16 tahun 2019 tentang penetapan Lahan Pertanian Pangan Berkelanjutan 
Perubahan spesifik dari penggunaan pertanian ke pemanfaatan non pertanian yang dikenal dengan istilah alih fungsi (konversi) lahan, kian waktu kian meningkat, fenomena ini dapat mendatangkan permasalahan yang serius di kemudian hari [15]. Jika tidak diantisipasi secara serius dari sekarang, alih fungsi lahan pertanian yang tidak terkendali dapat mengancam kapasitas penyediaan pangan (suplay) dari Kabupaten Indragiri Hilir, bahkan dalam jangka panjang dapat menimbulkan kerugian sosial. Konversi lahan sawah ke penggunaan nonpertanian dapat menimbulkan dampak negatif secara ekonomi, sosial dan lingkungan bagi ketahanan pangan nasional khususnya Kabupaten Indragiri Hilir [16], [17].

\subsection{Landasan Filosofis}

Sejak manusia pertama kali menempati bumi, lahan sudah menjadi salah satu unsur utama dalam menunjang kelangsungan kehidupan. Konkritnya, lahan difungsikan sebagai tempat manusia beraktivitas untuk mempertahankan eksistensi. Aktivitas yang pertama kali dilakukan adalah pemanfaatan lahan untuk bercocok tanam (pertanian). Kegiatan pertanian merupakan salah satu aktifitas paling mendasar bagi manusia, karena semua orang perlu makan setiap hari. Pengembangan usaha agribisnis menjadi pilihan sangat strategis dan penting sejalan dengan upaya pemerintah dalam mengembangkan sumber-sumber pertumbuhan ekonomi baru diluar minyak dan gas.

Dalam sejarah Indonesia pernah mampu mencapai swasembada pangan pada tahun 1984 melalui gerakan "Revolusi Hijau" yaitu gerakan untuk meningkatkan produksi pangan melalui usaha pengembangan teknologi pertanian. keberhasilan gerakan revolusi hijau merupakan bukti upaya pemerintah dalam meningkatkan kesejahteraan petani. Seiring pertumbuhan populasi dan perkembangan peradaban manusia, penguasaan dan penggunaan lahan mulai terusik. Keterusikan ini akhirnya menimbulkan kompleksitas permasalahan akibat pertambahan jumlah penduduk, penemuan dan pemanfaatan teknologi, serta dinamika pembangunan. Lahan yang semula berfungsi sebagai media bercocok tanam (pertanian), berangsur-angsur berubah menjadi multifungsi pemanfaatan.

Pembukaan Undang-Undang Dasar Negara Kesatuan Republik Indonesia Tahun 1945 menyebutkan bahwa tujuan bernegara adalah

"melindungi segenap bangsa Indonesia dan seluruh tumpah darah Indonesia dan untuk memajukan kesejahteraan umum, mencerdaskan kehidupan bangsa dan ikut melaksanakan ketertiban dunia yang berdasarkan kemerdekaan, perdamaian abadi, dan keadilan sosial". Oleh karena itu, perlindungan segenap bangsa dan peningkatan kesejahteraan umum adalah tanggung jawab penting bernegara. Apalagi menyangkut tentang perlindungan fungsi tanah oleh negara pada lahan pertanian terhadap alih fungsi lahan atau yang dikenal dengan konversi lahan.

Indonesia merupakan negara agraris yang diartikan tanah dan dihubungkan dengan usaha pertanian. Didalam kehidupan kita, tanah memiliki peranan yang sangat penting dalam kehidupan pembangunan bangsa, karena didalam konstitusi Undang- Undang Dasar Negara Kesatuan Republik Indonesia Tahun 1945 yang dituangkan dalam Pasal 33 ayat (3) menyebutkan bahwa: "Bumi dan air dan kekayaan alam yang terkandung didalamnya dikuasai oleh Negara dan digunakan untuk sebesar-besar kemakmuran rakyat".

Kita mengharapkan dengan adanya perangkat peraturan yang komprehensif terkait perlindungan lahan dan upaya pemberian insentif kepada petani maka diharapkan tanah tersedia bagi petani bukan hanya untuk menjamin ketersediaan produksi pangan, namun lebih jauh menjamin akses petani atas lahan untuk meningkatkan kesejahteraan petani. Indonesia dikenal sebagai negara lumbung padi yang artinya menghasilkan padi yang sangat banyak, baik untuk negara sendiri maupun diekspor ke negara lain. Tetapi saat sekarang ini kita merasakan jumlah rumah tangga dengan usaha pertanian terus menurun akibat beberapa hal diantaranya alih profesi dan semakin sempitnya lahan pertanian karena alih fungsi lahan untuk pembangunan infrastruktur, pembangunan pabrik dan perumahan.

\subsection{Landasan Sosiologif}

Lahan pertanian memiliki peran dan fungsi strategis bagi masyarakat Indonesia yang bercorak agraris. Sebagian besar penduduk Indonesia menggantungkan hidup pada sektor pertanian. Dalam posisi yang demikian lahan tidak saja memiliki nilai ekonomis, sosial bahkan secara filosofis lahan memiliki nilai religius. Dalam rangka pembangunan pertanian yang berkelanjutan, lahan merupakan sumberdaya pokok dalam usaha pertanian, terutama pada kondisi dimana sebagian besar bidang usaha yang dikembangkan masih tergantung kepada pola pertanian yang bersifat land based 
agricultural. Lahan merupakan sumberdaya yang unik dimana jumlahnya tidak bertambah, namun kebutuhan terhadap lahan selalu meningkat. Oleh karena itu, ketersediaan lahan merupakan syarat mutlak untuk mewujudkan peran sektor pertanian secara berkelanjutan, terutama dalam perannya mewujudkan ketahanan pangan nasional.

Konversi lahan pertanian menimbulkan dampak yang sangat besar terhadap ketahanan pangan. Lahan pertanian yang berubah fungsi akan mempunyai implikasi yang serius terhadap produksi pangan, fisik lingkungan, dan budaya masyarakat disekitar lahan yang dikonversi tersebut. Permasalahan semakin kompleks, karena konversi lahan pertanian subur belum diimbangi oleh upaya yang sistematis untuk dapat mengembangkan lahan yang potensial. Konversi lahan pertanian pangan menyebabkan semakin sempitnya luas garapan usahatani dan menurunnya tingkat kesejahteraan petani. Oleh karena itu, pengendalian konversi lahan pertanian pangan melalui perlindungan lahan pertanian pangan merupakan salah satu upaya untuk mewujudkan ketahanan dan kedaulatan pangan, dalam rangka meningkatkan kemakmuran dan kesejahteraan petani dan masyarakat.

Alih fungsi lahan adalah perubahan fungsi sebagian atau seluruh kawasan lahan dari fungsinya semula (seperti yang direncanakan) menjadi fungsi lain yang menjadi dampak negatif (masalah) terhadap lingkungan dan potensi lahan. Konversi lahan juga dapat diartikan sebagai perubahan untuk penggunaan lain disebabkan oleh faktor-faktor yang secara garis besar menurut Pasandaran, (2006), ada tiga faktor, baik sendiri-sendiri maupun bersamasama,yang merupakan determinan konversi lahan, yaitu kelangkaan sumber daya lahan dan air, dinamika pembangunan, dan peningkatan jumlah penduduk. Dampak dari konversi lahan tidak hanya dirasakan oleh para pemilik lahan, tetapi dapat dirasakan secara meluas oleh seluruh lapisan masyarakat. Reforma agraria tersebut mencakup upaya penataan yang terkait dengan aspek penguasaan/pemilikan serta aspek penggunaan/ pemanfaatan sebagaimana ditetapkan dalam Pasal 2 Ketetapan Majelis Permusyawaratan Rakyat Republik Indonesia Nomor IX/MPR-RI/2001 tentang Pembaruan Agraria dan Pengelolaan Sumber Daya Alam. alih fungsi lahan pada dasarnya terjadi akibat adanya persaingan dalam pemanfaatan lahan antara sektor pertanian dan sektor non pertanian.
Sedangkan persaingan dalam pemanfaatan lahan tersebut muncul akibat adanya tiga fenomena ekonomi dan sosial, yaitu 1) keterbatasan sumberdaya lahan, 2) pertumbuhan penduduk dan 3) pertumbuhan ekonomi. Luas lahan yang tersedia relatif terbatas, sehingga pertumbuhan penduduk akan meningkatkan kelangkaan lahan yang dapat dialokasikan untuk kegiatan pertanian dan non pertanian.

\section{KESIMPULAN DAN SARAN}

Pemerintah Kabupaten Indragiri Hilir khusus Dinas Pangan Tanaman Pangan Hortikultura dan Peternakan menargetkan diakhir tahun 2021 pendataan by name by addres sudah selesai dan membuat rancangan peraturan daerah tentang perlindungan lahan pertanian pangan berkelanjutan yang akan diajukan untuk dijadikan PERDA Kabupaten Indragiri Hilir. Luas lahan yang akan diusulkan nantinya akan sesuaikan dengan PERDA RTRW Kabupaten Indragiri Hilir, hal ini untuk menjaga kestabilan pertumbuhan perekonomian dan perkembangan perkotaan di Kabupaten Indragiri Hilir.

\section{UCAPAN TERIMA KASIH}

Ucapan terima kasih kepada Pemerinta Daerah Indragiri Hilir melalui Dinas Panga Tanaman Paangan Hortikultura dan Peternakan yang memberi suport dalam penelitian ini.

\section{DAFTAR PUSTAKA}

[1] W. Rahmawati, Y. A. Kusumastuti, and Nita Aryanti, "Karakterisasi Pati Talas (Colocasia Esculenta (L.) Schott) (Colocasia Esculenta (L.) Schott) Sebagai Alternatif Sumber Pati Industri Di Indonesia," J. Teknol. Kim. Dan Ind., vol. 1, no. 1, p. 348, 2012.

[2] Hartono, Kabupaten Indragiri Hilir Dalam Angka 2020. 2020.

[3] I. Iskandar, H. Miftah, and A. Yusdiarti, "Implementasi Program Perlindungan Lahan Pertanian Pangan Berkelanjutan (PLP2B) Di Kabupaten Garut Jawa Barat (Kasus di Desa Jati Kecamatan Tarogong Kaler Kabupaten Garut)," J. Agribisains, vol. 2, no. 2, pp. 11-21, 2017, doi: 10.30997/jagi.v2i2.775.

[4] S. R. Nurbaya and T. Estiasih, "Pemanfaatan Talas Berbanding Umbi Kuning ( Colocasia esculenta ( $\mathrm{L}$.) Schott ) Dalam Pembuatan Cookies 
Utilization of Yellow Corm Taro ( Colocasia esculenta ( $L$.) Schott ) in Producing Cookies," J. Pangan Dan Agroindustri, vol. 1, no. 1, pp. 46-55, 2013.

[5] D. Ikasari, S. Syamdidi, and T. D. Suryaningrum, "Penggunaan Bakteri Asam Laktat dan Lemak Sapi dalam Pengolahan Limbah Tuna menjadi Sosis Fermentasi," Jurnal Pascapanen dan Bioteknologi Kelautan dan Perikanan, vol. 6, no. 2. p. 101, 2011, doi: 10.15578/jpbkp.v6i2.402.

[6] M. Apriyanto and Rujiah, "Analisis Tingkat Ketahanan Pangan Terhadap Kerawanan Pangan Menggunakan Metode GIS ( Geographic Information System )," J. Food Syst. Agribus., vol. 5, no. 1, pp. 54-61, 2021.

[7] R. Kusniati, "Analisis Perlindungan Hukum Penetapan Lahan Pertanian Pangan Berkelanjutan," Inov. J. IImu Huk., vol. 6, no. No 2, pp. 1-30, 2013, [Online]. Available: onlinejournal.unja.ac.id/index.php/jimih/articl e/download/2115/1455.

[8] M. Ramli and M. Apriyanto, "Manajemen Keuangan Untuk Meningkatkan Perekonomian Keluarga Di Masa Pandemi COVID-19," Sellodang Mayang, vol. 6, no. 3, pp. 145-152, 2020.

[9] S. Muryono and W. Utami, "Pemetaan Potensi Lahan Pertanian Pangan Berkelanjutan Guna Mendukung Ketahanan Pangan," BHUMI J. Agrar. dan Pertanah. Receiv., vol. 6, no. 2, pp. 201-218, 2020.

[10] A. Amalina, S. D. Binasasi, and $H$. Purnaweni, "Formulasi Kebijakan Perlindungan Lahan Pertanian Pangan Berkelanjutan Di Kabupaten Karawang," Gema Publica, vol. 3, no. 2, p. 92, 2018, doi: 10.14710/gp.3.2.2018.92102.

[11] K. T. Ayunita, I. A. Putu Widiati, and I. N. Sutama, "Pengendalian Alih Fungsi Lahan Pertanian Pangan Berkelanjutan," J. Konstr. Huk., vol. 2, no. 1, pp. 160164, 2021, doi: 10.22225/jkh.2.1.2987.160-164.

[12] Y. Riono and M. Apriyanto, "Pemanfaatan Abu Sekam Padi dalam Inovasi Pemupukan Kacang Hijau (Vigna radiate L) Di Lahan Gambut," Selodang Mayang J. IIm. Badan Perenc. Pembang. Drh. Kabupaten Indragiri Hilir, vol. 6, no. 2, p. 60, 2020, doi: 10.47521/selodangmayang.v6i2.164.

[13] K. Novyar Satriawan Fikri and A. Azhar, "Implementation of Discipline Policy for Civil Servants in Indragiri Hilir Regency
Post Covid Pandemic 19," in Proceedings of the 5th NA International Conference on Industrial Engineering and Operations Management Detroit, Michigan, USA, August 10 - 14, 2020, 2020, pp. 2188-2191.

[14]A. Azhar, Syekh Abdurrahman Siddiq Tuan Guru Teladan Bangsa, vol. 1, no. 2. 2020.

[15] M. Taufik, A. Kurniawan, and F. M. Pusparini, "Penentuan Lahan Pertanian Pangan Berkelanjutan (Lp2B) Menggunakan Metode Multi Data Spasiali Di Kecamatan Ngadirojo, Kabupaten Pacitan," Geoid, vol. 13, no. 1, p. 63, 2018, doi: 10.12962/j24423998.v13i1.3679.

[16] Mulono Apriyanto, K. N. S. Fikri, V. A. Siregar, Jamri, and A. Azhar, "Penyuluhan Tentang Peremajaan Kelapa Sawit Dan Legalitas Lahan Di Kecamatan Kempas Kabupaten Indragiri Hilir," JPM J. Pengabdi. Masy., vol. 1, no. 1, pp. 1-6, 2020, doi: 10.31219/osf.io/7j4sy.

[17] Tedi Susilo; and M. Apriyanto, "Pengaruh Dua Hormon Pertumbuhan Dan Tiga Pupuk Kendang Formula Pada Varietas Papaya (Carica Papaya L.) Di Simpang Kiri, Kecamatan Pelangiran," J. Agro Indragiri, vol. 5, no. 1, pp. 6-11, 2020, doi: 10.32520/jai.v5i1.1451. 